\title{
EDUCAÇÃO SEXUAL: UMA SEQUÊNCIA DIDÁTICA PARA A EJA DE UMA ESCOLA DE ASSENTAMENTO
}

\author{
DANIELLY FERREIRA DIAS ${ }^{1}$ \\ ORCID: https://orcid.org/0000-0002-5148-3597 \\ NEUSA ELISA CARIGNATO SPOSITO ${ }^{2}$ \\ ORCID: https://orcid.org/0000-0001-7061-5711
}

\begin{abstract}
RESUMO: Este artigo é parte de uma pesquisa de intervenção pedagógica desenvolvida em um curso de mestrado. O objetivo foi investigar as concepções de sexualidade de alunos(as) da Educação de Jovens e Adultos (EJA) durante as aulas de Ciências, bem como propor uma Sequência Didática (SD) para a realização da Educação Sexual (ES) em uma escola alocada em um assentamento, na zona rural do município de Monte Alegre de Minas/MG. Incialmente, foi realizada uma revisão da literatura em buscas na internet pelas expressões "educação sexual na EJA em escolas de assentamento", "educação sexual na EJA e a abordagem freiriana" e por "gênero e sexualidade em EJA de assentamentos". Porém, não houve resultados para esta busca, e a realização desta pesquisa justifica-se devido à ausência de discussões que alinham a tríade EJA, ES e escola de assentamento. A coleta de dados foi realizada por meio de um questionário. Os resultados apresentaram sugestões e possibilidades de discussão das temáticas da sexualidade, inclusive de gênero, a partir das vivências destes(as) alunos(as). Sugere-se a elaboração de uma SD que se adeque à transversalidade das temáticas da sexualidade e à realidade dos(as) estudantes no contexto da tríade ES, EJA e escola de assentamento.
\end{abstract}

Palavras-chave: educação sexual, sexualidade, EJA, Ensino Fundamental II, escola de assentamento.

\section{SEXUAL EDUCATION: A TEACHING SEQUENCE FOR A YAE SETTLEMENT SCHOOL}

\begin{abstract}
This article is part of a pedagogical-intervention research developed in a master's course. The objective was to investigate sexuality conceptions of Youth and Adult Education (YAE) students during Science classes, as well as to propose a Didactic Sequence (DS) for Sexual Education (SE) in a school located in a settlement, in the rural area of Monte Alegre de Mina, a town in the state of Minas Gerais, Brazil. Initially, we did a literature review on the Internet searching for: "sex education in YAE in settlement schools", "sex education in YAE and the Freirean approach", and for "gender and sexuality in settlement YAE". However, there were no results for this search. Thus, this research is justified due to the lack of discussions that align the triad YAE, SE, and settlement school. Data collection used questionnaires. The results present suggestions and possibilities for discussing sexuality themes, including gender, based on students' experiences. It is suggested the development of DS adapted to the
\end{abstract}

\footnotetext{
${ }^{1}$ Universidade Federal de Uberlândia. MG, Brasil. < daniellyferreira001@hotmail.com>

2 Universidade Federal de Uberlândia. MG, Brasil. <neusa.ensino@gmail.com> Educação em Revista|Belo Horizonte|v.37|e231147|2021
} 
transversality of the sexuality themes and the reality of the students in the triad context of SE, YAE, and settlement school.

Keywords: sex education, sexuality, YAE, elementary school II, settlement school.

\section{EDUCACIÓN SEXUAL: UNA SECUENCIA DIDÁCTICA PARA LA EJA DE UNA ESCUELA DE ASENTAMIENTO}

RESUMEN: Este artículo es parte de una investigación de intervención pedagógica desarrollada en un curso de maestría. El objetivo fue investigar las concepciones de sexualidad de los estudiantes de Educación de Jóvenes y Adultos (EJA) durante las clases de Ciencias, así como proponer una Secuencia Didáctica (SD) para el logro de la Educación Sexual (ES) en una escuela asignada en un asentamiento, en la zona rural del municipio de Monte Alegre de Minas/MG. Inicialmente, se realizó una revisión de la literatura sobre búsquedas en Internet de las expresiones "educación sexual en EJA en escuelas de asentamiento", "educación sexual en EJA y el enfoque freiriano" y "género y sexualidad en EJA de asentamiento". Sin embargo, no hubo resultados para esta búsqueda y la realización de esta investigación se justifica debido a la ausencia de discusiones que alineen la tríada EJA, ES y la escuela de asentamiento. La recolección de datos se realizó mediante un cuestionario. Los resultados presentaron sugerencias y posibilidades para discutir los temas de sexualidad, incluso de género, basados en las experiencias de estos estudiantes. Se sugiere el desarrollo de SD que se adapte a la transversalidad de los temas de sexualidad y la realidad de los estudiantes en el contexto de la ES, EJA y la tríada de asentamiento escolar.

Palabras clave: educación sexual, sexualidad, EJA, escuela primaria II, asentamiento escolar.

\section{INTRODUÇÃO}

Este artigo é parte de uma pesquisa de dissertação de mestrado em Ensino de Ciências e Matemática de uma universidade federal brasileira. O presente estudo versa sobre a temática da Educação Sexual (ES) para os anos finais do Ensino Fundamental (EF), na modalidade Educação de Jovens e Adultos (EJA), no turno noturno, de uma escola de assentamento na zona rural, na cidade de Monte Alegre de Minas/MG. O seu objetivo foi propor e elaborar uma Sequência Didática (SD) para estes(as) estudantes com a temática da sexualidade, a partir do conhecimento teórico à luz da emancipação freiriana, que tem por base a educação dialógica e humanista ao considerar a realidade do(a) aluno(a).

Ao considerar a EJA como um espaço de vivências dinâmico, permeado não só por um tipo de sexualidade, mas por várias, oriundas de diferentes sujeitos e vivências, entre jovens e adultos(as) com questionamentos, situações polêmicas e omissas que necessitam ser discutidas e refletidas nas salas de aula, o que dizer, então, sobre os questionamentos de temas que perpassam a sexualidade de educandos(as) das turmas do EF II, na modalidade EJA, em uma escola de assentamento da rede pública estadual mineira?

$\mathrm{Na}$ tentativa de satisfazer a tais questionamentos nessa modalidade de ensino, surgiu a oportunidade de realizar, nas aulas de Ciências da Natureza, a presente pesquisa, considerando que estes sujeitos possuem conhecimentos aprendidos no dia a dia, os quais são compartilhados na forma de vivenciar seus corpos, educar os(as) filhos(as) e lidar com o outro cultural e socialmente. Tais conhecimentos evidenciaram a necessidade de elaboração de um material pedagógico que considerasse as reais necessidades desse grupo social, já que não existe a oferta de um material específico que ampare a particularidade deste estudo.

A pesquisa baseou-se nos referenciais teóricos de Louro (2007; 2016) e Foucault (1988), dentre outros(as) autores(as) como Rael (2007), Weeks (2016) e Silva (2015; 2018), que abordam questões pertinentes à sexualidade e ao gênero na educação. Também se buscou a temática em documentos educacionais, como a Lei de Diretrizes e Bases da Educação Nacional - LDBEN -(BRASIL, 1996), e, 
no que tange ao Ensino de Ciências, nos Parâmetros Curriculares Nacionais (PCN) - Temas Transversais (BRASIL, 1998) e na Base Nacional Comum Curricular - BNCC - (BRASIL, 2016; 2017; 2018).

Da mesma forma, a pesquisa amparou-se em autores(as) que fazem suas críticas a estes documentos educacionais, tais como Altmann (2001), Julião, Beiral e Ferrari (2017), Costa (2017), Machado (2017), Silva e Arantes (2017) e Souza Júnior (2018). Em Freire (1987), buscou-se a discussão da educação para massas populares quanto à Pedagogia do Oprimido e aos princípios da educação no Movimento Social dos Trabalhadores Rurais Sem Terra (MST).

No que tange à discussão temática deste estudo, foi realizada uma revisão sistemática e aprofundada da literatura na Associação Nacional de Pós-Graduação e Pesquisa em Educação (ANPED) no Grupo de Trabalho (GT) - 23 Gênero, Sexualidade e Educação -, considerando as expressões "educação sexual na EJA em escolas de assentamento", "educação sexual na EJA e a abordagem freiriana" e por "gênero e sexualidade em EJA de assentamentos". Porém, não houve resultados para essa busca, motivando o presente estudo, que alinha a tríade EJA, ES e escola de assentamento. A seguir, foram realizadas pesquisas na internet pelas mesmas expressões, encontrando-se o trabalho de autores(as) como Prado e Reis (2012), Soares e Gastal (2012), Santiago (2014) e Zanatta et al. (2016), com os quais dialogaremos.

A presente pesquisa foi submetida ao Comitê de Ética em Pesquisa com Seres Humanos (CEP), da Universidade Federal de Uberlândia (UFU), sendo aprovada em 23/10/2018, sob o número 83997318.0.0000.5152.

\section{EDUCAÇÃO SEXUAL NA ESCOLA}

Segundo Louro (2016), a sexualidade como uma construção a todos os seres humanos pode ser entendida como a identidade social, sexual e de gênero do sujeito modelada por instâncias sociais e culturais, ao que Foucault (1988) chamou de "dispositivo histórico".

Neste sentido,

[...] não se deve concebê-la como uma espécie de dado da natureza que o poder é tentado a pôr em xeque, ou como um domínio obscuro que o saber tentaria, pouco a pouco, desvelar. A sexualidade é o nome que se pode dar a um dispositivo histórico: não à realidade subterrânea que se apreende com dificuldade, mas à grande rede da superfície em que a estimulação dos corpos, a intensificação dos prazeres, a incitação ao discurso, a formação dos conhecimentos, o reforço dos controles e das resistências, encadeiam-se uns aos outros, segundo algumas grandes estratégias de saber e poder (FOUCALT, 1988, p. 100).

Justificando a dimensão social, cultural e, mesmo, política, Louro (2016) argumenta que, embora seja uma característica comum, a sexualidade não é um processo natural vivenciado igualmente pelos corpos, já que existe uma condição plural que emerge do coletivo, de uma construção social, a qual é refletida por toda a vida do cidadão. Para esta autora, quanto à naturalidade da sexualidade,

[...] aceitando essa ideia, fica sem sentido argumentar a respeito de seu caráter construído. A sexualidade seria algo "dado" pela natureza, inerente ao ser humano. Tal concepção usualmente se ancora no corpo e na suposição de que todos vivemos nossos corpos, universalmente, da mesma forma. No entanto, podemos entender que a sexualidade envolve rituais, linguagens, fantasias, representações, símbolos, convenções... Processos profundamente culturais e plurais. Nessa perspectiva, nada há de exclusivamente "natural" nesse terreno, a começar pela própria concepção de corpo, ou mesmo de natureza (LOURO, 2016, p. 11).

Nesse contexto, a sexualidade é vista como um dispositivo histórico de formação social e cultural intercruza diferentes ambientes, dentre eles, a religião, a mídia, a família e a escola (BRASIL, 1998; RAEL, 2007; ZANATTA et al., 2016). Dessa forma, as marcas que são adquiridas pelas pessoas, nessas instâncias sociais, referem-se às situações cotidianas e às experiências relacionadas com a construção de suas identidades sociais, sexuais e de gênero (LOURO, 2016). 
Segundo Louro, todos esses espaços sociais realizam as pedagogias da sexualidade, ou seja, o "disciplinamento dos corpos" (LOURO, 2016, p. 17), que reiteram identidades e práticas da "“norma" desejada" (LOURO, 2016, p. 18), que ora subordina, ora nega ou recusa outras identidades e práticas, consideradas divergentes, alternativas e contraditórias - dessa forma, além das identidades sociais (raça, nacionalidade, classe etc.), inserem-se aqui identidades sexuais e de gênero com o caráter instável, histórico e plural. E, no processo de reconhecimento de identidades, inscreve-se a atribuição de diferenças com seus padrões culturais (LOURO, 2016).

Nessa conjuntura, a família em seu processo de ES é um fator importante na construção de saberes da sexualidade, que se estabelece por laços afetivos de confiança. Ela é a primeira instância social em que a educação sexual ocorre.; nela se ensinam valores morais, atitudes, crenças religiosas e opiniões (BRASIL, 1998). Mesmo aquela família que não fala, discute ou educa sexualmente seus(suas) filhos(as) está realizando uma ES que é silenciada, na qual os membros familiares subentendem que sexualidade é assunto privado e particular que não merece ou não deve ser discutido ou falado. No entanto, ainda assim a sexualidade existe e se faz presente nos corpos dos sujeitos que a negam ou a silenciam em seus discursos, sendo, pois, compartilhada nos espaços sociais e também modelada pelos meios de comunicação (LOURO, 2016; WEEKS, 2016).

A mídia, em seus diversos meios de comunicação, veicula informações que são atribuídas ao molde de valores e comportamentos repassados pela família, ora reforçando conhecimentos compartilhados, ora com novas informações, ora perpetuando preconceitos (BRASIL, 1998). Até mesmo "os desenhos animados, por sua circulação, constituem-se em um importante artefato cultural do século XXI (...), veiculando determinados discursos sobre gênero, sexualidade, raça.” (RAEL, 2007, p. 160, 162).

A escola, como importante instância social e espaço de vivências e formação de vários tipos de sexualidade, deve possibilitar a discussão e reflexão dos saberes, valores e das atitudes já estabelecidas acerca da sexualidade (ZANATTA et al., 2016). Sua função é complementar, informar, problematizar e politizar a diversidade de olhares, e não substituir ou menosprezar a função da família (BRASIL, 1998). Nesta ótica, Soares e Gastal (2012) afirmam que as aulas de Ciências são um espaço adequado para a realização da ES de forma transversal.

Contudo, esses espaços não são lugares fixos, mas ambientes dinâmicos, flexíveis e plurais, nos quais se adquirem marcas a partir das relações e interações sociais aí vivenciadas, e nos quais as referidas pedagogias estabelecem o "disciplinamento dos corpos".

No que se refere à discussão pedagógica da ES na escola, esta tem respaldo legal amparado por documentos curriculares: primeiro, pelos PCN desde 1997, e, atualmente, pela BNCC, aprovada em dezembro de 2017.

Os PCN são diretrizes educacionais que abordam todas as áreas do conhecimento e temas transversais a eles ligados de forma interdisciplinar. Os temas transversais são temas cotidianos de relevância que perpassam a realidade do(a) aluno(a) e as diferentes disciplinas curriculares, caracterizando a interdisciplinaridade.

A perspectiva pedagógica do trabalho de ES adotada pelos PCN é que os(as) alunos(as) possam vivenciar a "sexualidade com prazer e responsabilidade" (BRASIL, 1998, p. 311), sendo a sexualidade um dos temas para a promoção da saúde, referenciada neste documento.

No entanto, Altmann (2001) aponta falhas nos PCN ao se contemplar a sexualidade nos currículos escolares. A autora menciona que a intervenção pedagógica deste tema transversal visa ao autocuidado e o autodisciplinamento dos corpos por meio da modelagem dos comportamentos, das atitudes higienistas, preventivas às ISTs/AIDS, gravidez indesejada, sobretudo na adolescência e, também, curativas, ao proporcionar uma vivência segura e prazerosa da sexualidade referente à saúde, não fazendo relação histórica para a desconstrução da discriminação do gênero e do preconceito.

Ainda que o documento admita manifestações diversificadas da sexualidade, ele não problematiza a categoria sexualidade sob o ponto de vista de sua constituição histórica, da mesma forma que em relação a outras categorias, como homossexualidade e heterossexualidade. (...) Defender a sexualidade como algo ligado ao prazer e à vida não diz muito e não é suficiente para desvinculá-la de tabus e preconceitos (ALTMANN, 2001, p. 581). 
Em consonância com Altmann (2001), Louro (2007) discorre que, quanto à discussão de gênero e sexualidade nos currículos escolares, esta ainda atribui uma visão antirreflexiva: a norma heterossexual estabelece que o afastamento deste padrão significa tornar-se diferente, excêntrico.

Uma noção singular de gênero e sexualidade vem sustentando currículos e práticas de nossas escolas. Mesmo que se admita que existem muitas formas de viver os gêneros e as sexualidade, é consenso que a instituição escolar tem obrigação de nortear suas ações por um padrão: haveria apenas um modo adequado, legítimo, normal de masculinidade e de feminilidade e uma única forma sadia e normal de sexualidade, a heterossexualidade; afastar-se desse padrão significa buscar o desvio, sair do centro, torna-se excêntrico (LOURO, 2007, p. 43-44).

Da mesma forma, para Souza Junior (2018), a discussão da sexualidade nos PCN não induz a uma reflexão prazerosa ou a uma vivência pluralista, mas, sim, a uma solução para a gravidez indesejada entre os jovens e para a contaminação pelo vírus da AIDS que o País vivenciava. Para ele, "os debates mencionados sobre a sexualidade tiveram o efeito de aproximá-los a ideias de risco e de ameaça, devido aos problemas que a sociedade vinha apresentando, como o crescimento da epidemia do HIV/AIDS, ao invés de proporcionar caminhos ao prazer e à vida" (SOUZA JUNIOR, 2018, p. 19). Portanto, uma "discussão bem pertinente para a época e atualmente" (SILVA; ARANTES, 2017, p. 5).

Nos dias atuais, a proposta dos PCN vem sendo substituída pela da BNCC. A BNCC é um documento que enfatiza a regulamentação em nível nacional das diferentes modalidades de ensino da Educação Básica com o propósito pedagógico de uma formação cidadã integral, levando-se em consideração as características locais, sociais, regionais e socioculturais da comunidade escolar (BRASIL, 2018), inclusive para indivíduos que não tiveram a oportunidade de concluir os estudos em idade apropriada com o período escolar (COSTA, 2017).

Em sua versão inicial, leva em consideração "a abordagem de temas contemporâneos que afetam a vida humana em escala local, regional e global, preferencialmente de forma transversal e integradora [...] destacando-se temas como sexualidade, gênero e diversidade cultural" (BRASIL, p. 1314, 2016b). No entanto, em sua última versão, aprovada em dezembro de 2017, exclui questões ligadas ao gênero, restando apenas algumas questões ligadas à sexualidade, tais como diferenças entre o biológico, a reprodução, a contracepção e as medidas preventivas e curativas (SOUZA JUNIOR, 2018).

Santos, Pereira e Soares (2018) alertam que essa reformulação ao "suprimir esses temas da BNCC reflete uma visão conservadora, como uma ameaça à chamada 'família tradicional', mas acima de tudo desconsidera o acúmulo de debates, pesquisas e conquistas dos movimentos sociais em busca da equidade de direitos." (SANTOS; PEREIRA; SOARES, 2018, p. 11).

Para Souza Junior (2018), "houve um retrocesso sobre a discussão sobre gênero e sexualidades (...) atendendo aos pedidos da bancada fundamentalista/tradicional presente no Congresso Nacional" (SOUZA JUNIOR, 2018, p. 19), o que demonstra o engessamento da temática nos documentos curriculares.

Silva e Arantes (2017) discutem que, mesmo a educação sexual sendo suprimida na última versão da BNCC, este documento é norteador dos currículos escolares no âmbito nacional; assim, devem-se considerar as particularidades regionais, culturais e sociais, subentendendo-se, de forma implícita, que cabe às escolas incluir ou não as discussões sobre a temática.

Essas mesmas autoras defendem que "faz-se necessário essa discussão, já que, esses temas vinham sendo encarados com um pouco mais de naturalidade e seriedade e se houver uma retirada, todo o processo construído pode gerar um retrocesso" (SILVA; ARANTES, 2017, p. 1).

$\mathrm{Na}$ modalidade da EJA, é válido salientar que ambos os documentos referenciais apresentam a carência de propostas em comum no que tange à especificidade de temas da sexualidade nesta modalidade, considerando-se a presença de jovens, adultos(as) e idosos(as). Então, há a necessidade de se pensar, de refletir e de capacitar as práticas educativas nesse modelo.

A carência de aporte documental e de discussão quanto à forma de se trabalhar a diversidade sexual também atinge as escolas dos assentamentos, que têm sua proposta amparada na pedagogia da emancipação freiriana, que prima pelo diálogo, pela autonomia e pela libertação dos métodos opressores ao levar em conta a realidade do(a) aluno(a) (ZANATTA et al. 2016). 
Zanatta et al. (2016), ao considerarem a realidade das escolas dos assentamentos, acreditam que a solução pode estar na adoção de uma postura flexível do(a) professor(a), tendo por base o diálogo, evitando-se a postura unilateral, o autoritarismo e o preconceito. Nesse cenário, as diferentes abordagens de como o tema sexualidade pode ser discutido possibilitam a sensibilização e motivação do(a) aluno(a), provocando o seu interesse e a reflexão de seu comportamento e, consequentemente, sua possível interação em atividades, tais como oficinas, dinâmicas, discussões etc., que proporcionem e garantam um entendimento e uma compreensão vista de outra dimensão.

Assim, a escola é um espaço privilegiado para reflexão e formação da consciência política e social dos(as) estudantes, visto que os(as) jovens e adultos(as) possuem uma bagagem de conhecimentos (BRASIL, 1998; FREIRE, 1987). Dessa forma, o tratamento de temáticas ligadas à sexualidade na EJA é necessário, porque eles(as) também são educadores(as) do outro, contribuindo para o desenvolvimento pessoal, cultural, histórico, social e político.

\section{A EDUCAÇÃO DE JOVENS E ADULTOS E A DISCUSSÃO EM TORNO DA SEXUALIDADE}

A EJA perpassa todos os níveis da Educação Básica do País, em curto prazo de tempo, desde a Alfabetização até o Ensino Médio, oferecendo um ensino gratuito, noturno e adequado às condições do estudante, nas redes privada e pública preferencialmente, garantindo o seu acesso e a permanência na escola. Essa modalidade de ensino oferece estudos em curto prazo de tempo "destinada àqueles que não tiveram acesso ou continuidade de estudos no ensino fundamental e médio na idade própria" (BRASIL, 1996, p. 15). Para Julião, Beiral e Ferrari (2017),

Com a LDB, a EJA passa a ser concebida como uma modalidade da Educação Básica, o que lhe confere uma dimensão diferente daquela de outrora, na medida em que possibilita a superação da concepção de oferta aligeirada, compensatória e supletiva de escolarização. (JULIÃO, BEIRAL e FERRARI, 2017, p. 3).

Com base nesses autores, compreende-se que a LDBEN atribui características educacionais próprias do(a) aluno(a) no processo de ensino e aprendizado, adequando-se às suas necessidades, aos seus interesses e às suas vivências cotidianas, agregando flexibilidade e qualidade ao ensino e, assim, garantindo a dialética entre educação e cidadania, fazendo valer o pleno desenvolvimento do educando.

Quanto aos(às) alunos(as) da EJA, estes(as) fazem parte de um grupo escolar específico e dinâmico constituído por jovens, adultos(as) e idosos(as). De acordo com Prado e Reis (2012), Zanatta et al. (2016) e Costa (2017), geralmente todos são trabalhadores(as) na busca por melhores condições de vida, através dos estudos, satisfazendo-se com a conclusão do ensino fundamental e médio.

No entanto, Santiago (2014) alerta que "a EJA não existe somente para suprir carências, ela é um direito de indivíduos que trazem trajetórias escolares específicas e histórias de vida singulares" (SANTIAGO, 2014, p. 1). Desse modo, Silva $(2015,2018)$ argumenta que atender às especificidades de jovens e adultos é adensar reflexões desses sujeitos nas propostas pedagógicas da modalidade EJA.

Todavia, falar da EJA significa falar dos sujeitos que demandam essa modalidade, contribuindo para a percepção da educação como direito subjetivo de todos os sujeitos jovens, adultos(as) e idosos(as), independente da idade, classe social, gênero, raça/cor, condição sexual, de ser morador do campo, da periferia, das vilas ou favelas.

Quanto aos motivos que levaram estes sujeitos a não concluirem os estudos regulares, Prado e Reis (2012), Zanatta et al. (2016) e Costa (2017) mencionam alguns: dificuldades financeiras, maternidade, não conciliação entre tempo para estudo e tempo para trabalho, desinteresse pelas aulas, falta de motivação, dificuldades de aprendizagem e de acesso à escola etc.

Entretanto, é inegável que estes sujeitos, mesmo não tendo concluído seus estudos, apresentam saberes e vivências distintas quanto às diferentes identidades que formam e que constituem o espaço escolar (COSTA, 2017). Tais saberes, muitos deles essenciais e inerentes à vida, como as temáticas ligadas à sexualidade, são ignorados na modalidade EJA, prejudicando "o desenvolvimento da 
autonomia dos/as sujeitos/as, suas trajetórias de empoderamento e reconhecimento de si" (COSTA, 2017, p. 2), no retorno deste público nas salas de aulas. Quando abordadas, referem-se apenas a uma dimensão clínica dos corpos tratadas nos livros didáticos da EJA, deixando de lado as dimensões sociais e culturais da sexualidade (ZANATTA et al. 2016).

Ao compreender a escola como um espaço sociocultural (COSTA, 2017) e como um espaço de interação e formação de várias identidades de sujeitos (LOURO, 2016; WEEKS, 2016; COSTA, 2017), torna-se impossível a não discussão da transversalidade em torno dos temas da sexualidade, a qual, por sua vez, vai além do aspecto biológico.

Aos(às) professores(as) cabem a abordagem e a discussão de temáticas ligadas à necessidade e às vivências do(a) aluno(a), como também da globalização de assuntos pertinentes da atualidade, inclusive nos movimentos sociais. Dessa forma, entende-se que as discussões em torno da sexualidade e do gênero nos espaços escolares têm respaldo por meio de atividades didáticas realizadas por professores(as). Segundo Barreiro e Martins (2016), esses debates se tornam uma importante medida educativa para a construção do saber. Nesta sintonia, Julião, Beiral e Ferrari (2017) acrescentam que "considerar o pleno desenvolvimento da pessoa é fazê-la perceber que o pertencimento sociocultural se constrói em conjunto com os pressupostos escolares articulados com seus anseios e vivências" (JULIÃO; BEIRAL; FERRARI, 2017).

\section{ESCOLA DE ASSENTAMENTO}

As escolas de assentamento, diferentes das tradicionais escolas rurais, surgem no contexto da conquista à educação, o que dá maior garantia e estabilidade na luta por posses de terras. Quando incorporadas à rede pública de ensino, ou seja, quando se tornam regularizadas, essas escolas passam a ser denominadas Escolas do Campo (EC) (MEIRELLES; SALLA, 2014).

A escola reivindicada pelos movimentos sociais busca a promoção e a garantia dos direitos sociais de uma parcela significativa da realidade que, historicamente, foi excluída de exercer plenamente a sua cidadania. A EC surge em contraposição à lógica educativa capitalista (MOLINA; SÁ, 2012).

Para Machado (2017), a LDBEN, embora surja no âmbito da democratização da educação do País e oriente para a elaboração de uma proposta pedagógica, não faz relação com as práticas pedagógicas considerando as adequações de local, região, povos etc. Faz, sim, uma padronização, retirando dos(as) alunos(as) as capacidades e potencialidades individuais, resultando em um sistema de ensino padrão.

Dessa forma, as EC alocadas em assentamentos da reforma agrária e vinculadas ao MST têm suas propostas políticas pedagógicas pautadas na pedagogia de Freire, na qual o diálogo é o instrumento para o conhecimento, a autonomia e a práxis. Nesta perspectiva, a principal contribuição da abordagem freiriana advém da Pedagogia do Oprimido, cuja concepção humanista e libertadora colabora para a transformação social do sujeito oprimido ante a reflexão dos fatores opressores a que foi imposto, propiciando uma reflexão crítica e ética da sua realidade (MST, 2006).

Portanto, as práticas pedagógicas devem partir do interesse, da necessidade e dos conhecimentos do(a) educando(a) do campo a partir da sua trajetória de luta por seu espaço social, a fim de que sejam capazes de compreender a sua realidade e transformação social. Contudo, as EC são espaços sociais de participação ativa, investigação, ação e reflexão, de teoria e prática, de ensino e pesquisa (ZANATTA et al., 2016).

No entanto, a escola localizada no assentamento Roseli Nunes III é uma extensão de uma escola pública estadual e, por isso, ainda não é reconhecida como EC, pois não possui um Projeto Político Pedagógico (PPP) próprio, os(as) profissionais da educação não são capacitados(as) para a realidade do campo e, nesse espaço social, não se leva em consideração a realidade local dos(as) educandos(as).

\section{METODOLOGIA}

Esta pesquisa, na forma de intervenção pedagógica, envolve "o planejamento e a implementação de interferências (mudanças, inovações) - destinadas a produzir avanços, melhorias, nos 
processos de aprendizagem dos sujeitos que delas participam - e a posterior avaliação dos efeitos dessas interferências." (DAMIANI et al., 2013, p. 58).

Para Damiani et al. (2013), a intervenção pedagógica assume caráter qualitativo por ser regida por princípios, procedimentos e critérios, cuja "intenção é descrever detalhadamente os procedimentos realizados, avaliando-os e produzindo explicações plausíveis, sobre seus efeitos, fundamentadas nos dados e em teorias pertinentes" (DAMIANI et al., 2013, p. 59).

Ainda de acordo com essa autora, as intervenções pedagógicas são pesquisas aplicadas que têm o objetivo de contribuir para a resolução de problemas de ordem prática. Nesse contexto, segundo Fachin (2006) e Bell (2008), os questionários podem ser utilizados como instrumentos auxiliares de pesquisa aplicados no início e no fim da investigação.

Em sintonia com Fachin (2006), Bell (2008) e Damiani (2013), Martins (2006) e Carvalho (2006) ressaltam que a metodologia de pesquisa emerge dos questionamentos a serem resolvidos e que os questionários são apenas um instrumento de coleta de dados que visam levantar tópicos a serem solucionados via diálogo. Portanto, acredita-se que as interações discursivas no processo de ensino e aprendizagem, em seu contexto histórico e social, trazem consigo reflexões e novos olhares para o problema conhecido (MARTINS, 2006).

Decorrida a autorização da direção escolar para a participação na pesquisa, o público alvo deste estudo tomou conhecimento dessa iniciativa por meio da professora pesquisadora, nas aulas de Ciências da Natureza. Para os(as) alunos(as), foi disponibilizado o Termo de Consentimento Livre e Esclarecido (TCLE), fundamentado pelas resoluções $n^{\circ}$. 466/12 e $n^{\circ} .510 / 16$, preconizadas pela Comissão Nacional de Ética em Pesquisa (CONEP) do Conselho Nacional de Saúde (CNS) pertencente ao Ministério da Saúde (MS).

A metodologia contou com duas fases: aplicação de um questionário e elaboração da Sequência Didática (SD). Na primeira fase, o questionário buscou caracterizar os sujeitos da pesquisa quanto à idade, religião, ao sexo, à cor etc., e, também, com relação às suas concepções sobre a sexualidade, como adquirem informações e quais as dúvidas ou curiosidades que têm sobre o tema. Tais informações ajudaram a compor a próxima fase de elaboração das atividades, considerando a natureza das vivências na zona rural, suas necessidades e temas de interesse.

O questionário foi elaborado e desenvolvido pela pesquisadora depois de decorridas leituras sobre o tema e sobre a metodologia para elaborar questionários descritos por Bell (2008), contendo questões abertas e na forma de listas (com opções para marcar). A coleta de dados ocorreu por meio dos questionários aplicados, considerados por Fachin (2006) e Bell (2008) como instrumentos de dados, sendo um aplicado no início da investigação.

A análise dos dados ocorreu através dos questionários devidamente codificados. Cada participante foi identificado(a) por uma numeração arábica, sexo e período da EJA que frequentava, ou seja, Q1F, $1^{\circ}$ EJA; Q2F, $2^{\circ}$ EJA; e, assim, sucessivamente, assegurando-se o anonimato do(a) participante.

Após a codificação dos questionários, as respostas dos(as) participantes foram transcritas e organizadas de acordo com a identificação em ordem crescente de cada participante. É válido salientar que, após a transcrição dos dados, os questionários foram descartados, garantindo a confidencialidade. Com a análise realizada, emergiram as possibilidades temáticas a serem abordadas nas atividades para a SD.

A segunda fase contou com o planejamento de uma SD de forma sistemática e que fosse embasada em referenciais teóricos, cuja finalidade seria trabalhar temas e atender às sugestões dadas pelos(as) alunos(as).

\section{RESULTADOS E DISCUSSÕES}

\section{Primeira fase: aplicação do questionário}

\section{Perfil dos(as) estudantes da EJA da escola no assentamento}


Consentiram em participar da pesquisa todos(as) os(as) 26 estudantes da escola do assentamento. Desse grupo, uma aluna pertence ao $1^{\circ}$ Período, seis alunos(as) ao $2^{\circ}$ Período, oito alunos(as) ao $3^{\circ}$ Período e 11 alunos(as) pertencem ao $4^{\circ}$ Período da modalidade EJA, com idades entre 27 e 82 anos, sendo oito do sexo masculino e 18 do sexo feminino.

De acordo com o Instituto Brasileiro de Geografia e Estatística (IBGE), a classificação da população por faixas etárias dá-se da seguinte forma: indivíduos entre 0 e 19 anos são considerados jovens; de 20 a 59 anos, adultos(as); e as pessoas que têm 60 anos de idade ou mais são consideradas idosas (IBGE, 2010). Portanto, os(as) participantes agrupavam-se em duas das categorias de classificação etária do IBGE. Duas alunas foram consideradas idosas, e os(as) demais, que representam a maioria, enquadravam-se na classificação de adultos(as).

Dos sujeitos pesquisados, 20 faziam parte do Movimento dos Trabalhadores Rurais Sem Terra (MST), estando seus lotes/propriedades agrícolas instalados no assentamento denominado Roseli Nunes III; e seis pertenciam ao Banco da Terra, ambas organizações fundiárias do programa governamental da Reforma Agrária.

Todos(as) os(as) pesquisados(as) são de origem brasileira, embora de diferentes localidades regionais do País, e já frequentaram a escola em alguma fase anterior de suas vidas - na infância, na adolescência ou na juventude. Apresentavam diferentes estados civis, variando em maior número entre casados(as) (10); união estável (6); solteiros(as) (6); divorciados(as) (2); e viúvas (2). Assim, também divergiam quanto à religião, estando representados(as), respectivamente, por evangélicos(as) (11); católicos(as) (10); espíritas (4); e nenhuma crença (1). Quanto à cor da pele, declaravam-se como brancos(as) (12); pardos(as) (8); e negros(as) (6). Quanto à profissão, a maioria era produtor(a) rural (24), devido à condição de assentados(as); e outros eram artesã (1) e pedreiro (1) locais.

A investigação exploratória quanto ao perfil dos(as) jovens e adultos(as) foi ao encontro dos trabalhos de Prado e Reis (2012) e Silva (2015): todos os sujeitos pesquisados eram trabalhadores(as), diversificavam-se quanto às crenças religiosas, imigraram de diferentes localidades, exerciam diferentes atividades e ainda compartilhavam a rotina diária do trabalho com os estudos noturnos.

Daí a importância de os(as) profissionais da educação da EJA reconhecerem as singularidades de cada aluno(a), considerando as suas experiências de vida no processo de ensino aprendizagem, na ministração de conteúdos, programáticos ou complementares, que tenham assimilação e significado na vida desse(a) aluno(a) subornado(a) por uma sociedade dominante (FREIRE, 1987). Dentre esses conteúdos, as temáticas da sexualidade faziam-se presentes como atributo inerente a cada sujeito, considerando o seu histórico cultural e social.

Neste contexto, Silva (2018), em seu estudo sobre a Diversidade Sexual na Educação de Jovens e Adultos (EJA), ressalta que

[...] reconhecer as especificidades dos sujeitos significa legitimar as características pessoais, culturais e sociais, bem como, os desejos, os sonhos, as expectativas e as subjetividades de cada educando/a. Significa ouvi-los sobre suas individualidades e, principalmente, considerar as diferenças, incluindo a orientação sexual e as identidades de gênero (SILVA, 2018, p. 1).

De acordo com Prado e Reis (2012) e Silva (2015, 2018), Damiani et al. (2013) salientam que as pesquisas qualitativas vão além da identificação de características, proporcionando uma visão do problema, que foi obtida graças à exploração de suas particularidades. Tais variáveis, presentes na existência dos sujeitos, permitem a abordagem de temáticas com embasamentos científicos, que deem significados aos conhecimentos cotidianos e distintos desse grupo de alunos(as).

\section{Concepções sobre sexualidade}

Ao dar introdução a futuras discussões no delineamento de atividades de ES, iniciou-se com a pergunta aberta $O$ que você sabe sobre sexualidade? De acordo com as respostas, pôde-se definir sexualidade como um conceito presente no conhecimento destes(as) alunos(as). A seguir, destacam-se algumas concepções de sexualidade. 
É sexo (prazer carnal). (Q2F, 20 EJA)

Eu entendo sobre transexualidade, naquela novela em que a menina se transforma em menino. (Q4M, $2^{\circ}$ EJA)

Tipo homem com homem eu acho que não é normal, mas a gente também não pode discordar, porque eles gostam. (Q7F, 2 $\left.{ }^{\circ} \mathrm{EJA}\right)$

É se é feminino ou masculino. (Q8F, $\left.3^{\circ} \mathrm{EJA}\right)$

Sexualidade é particularidade, cada pessoa tem o sexo que se identifica. (Q20M, $\left.4^{\circ} \mathrm{EJA}\right)$

Eu sei que tem que prevenir é o comportamento. (Q23F, 4 EJA)

É sexo, comportamento, tipo de roupa, postura, mas não sei explicar escrevendo. (Q25F, 4 EJA)

Todos(as) os(as) participantes souberam dizer o que é sexualidade, da forma como a vivenciaram e vivenciam. Além disso, os reflexos da educação sexual de cada um dos sujeitos são sentidos nos convívios sociais, como na escola, por exemplo.

De acordo com os registros dos(as) alunos(as), foi possível destacar que as concepções de sexualidade expressavam dois destaques principais: o sexo para a obtenção do prazer do corpo pela satisfação do desejo erótico; e o gênero nas diferentes formas de ser homem e ser mulher, associando-o quanto à orientação sexual, rotulação de comportamento e corporificação das genitálias.

A sexualidade tida como sinônimo de sexo, apenas para o prazer carnal, do ato sexual em si, do coito, remonta ao caráter biologista e reprodutivo. No entanto, o sexo, como afirma Foucault (1988), é apenas um atributo da sexualidade. O gênero, por sua vez, abre uma discussão da comparação com os padrões de normalidade tidos entre homens e mulheres, normalidade esta estereotipada pela sociedade e a sua vinculação ao respeito, à diversidade sexual e às relações de poder.

Para Foucault (1988), a sexualidade deve ser o princípio da abertura de discussão nas relações de poder, flexível e articulável nos diálogos sociais.

\begin{abstract}
Não se deve descrever a sexualidade como um ímpeto rebelde, estranha por natureza e indócil por necessidade, a um poder que, por sua vez, esgota-se na tentativa de sujeitá-la e muitas vezes fracassa em dominá-la inteiramente. Ela aparece mais como um ponto de passagem particularmente denso pelas relações de poder; entre homens e mulheres, entre jovens e velhos, entre pais e filhos, entre educadores e alunos, entre padres e leigos, entre administração e população. Nas relações de poder, a sexualidade não é o elemento mais rígido, mas um dos dotados da maior instrumentalidade: utilizável no maior número de manobras, e podendo servir de ponto de apoio, de articulação às mais variadas estratégias (FOUCAULT, 1988, p. 98).
\end{abstract}

Para Louro (2016), as identidades sexuais e de gênero são afirmadas ou silenciadas pelas mais diferentes instâncias sociais, dentre elas, a família, a religião, a mídia e a escola, legitimando algumas e reprimindo outras, exercendo o que esta autora denomina de pedagogias da sexualidade.

Neste viés, "todas essas instâncias realizam uma pedagogia, fazem um investimento que, frequentemente, aparece de forma articulada, reiterando identidades e práticas hegemônicas enquanto subordina, nega ou recusa outras identidades e práticas" (LOURO, 2016, p. 25). Dessa forma, entendese que a escola, como uma instância que dita as suas pedagogias da sexualidade, deve ser um local de conhecimento, reflexão e não de ocultamento do saber e restrição.

E que, portanto, considera-se que cada pesquisado(a), em detrimento de suas vivências, carrega conceitos próprios sobre o que vem a ser a sexualidade. Daí a importância de se agregarem informações a esses conhecimentos já existentes, de forma adequada, na desconstrução de estereótipos e tabus para a promoção do saber e da autonomia dos(as) educandos(as).

\title{
Fontes de informações sobre sexualidade
}

Entre as instâncias, nas quais os(as) participantes adquirem informações sobre sexualidade, estes(as) afirmaram que agregam tais conhecimentos nos programas de televisão (20,5\%), tais como 
filmes, novelas etc., seguidos da família (17,9\%), das rodas de amigos(as) (16,7\%), das revistas (15,4\%) e da internet $(15,4 \%)$, assim como através de outros meios de veiculação de informação, como a escola $(12,8 \%)$ e, por último, a religião $(1,3 \%)$.

Constata-se como a mídia televisiva influencia a formação do autoconhecimento em relação até mesmo à família, na qual a educação sexual deveria ser motivo de diálogo e de compreensão. "A mídia, nas suas múltiplas manifestações, e com muita força, assume relevante papel, ajudando a moldar visões e comportamentos" (BRASIL, 1998, p. 292), embora ela também informe, moralize e reforce estereótipos, da mesma forma como o faz a escola, a família e a religião.

Destaca-se, então, a importância da escola, indicada como quinta instância social de formação do saber do alunado, a partir de suas vivências e condições de conhecimento. À escola cabe trabalhar o respeito às diferenças, o diálogo sobre crenças, tabus e mitos, a discussão de valores associados à sexualidade, sem julgar ou violar o comportamento dos(as) alunos(as) e os padrões de educação sexual que cada família oferece a seus(suas) filhos(as) (BRASIL, 1998).

Nesse contexto, cabe à EJA, considerando as especificidades e vivências de seus(suas) alunos(as), compartilhar os conhecimentos do senso comum com informações esclarecedoras e reflexivas, evitando-se possíveis julgamentos normalizadores concebidos e repassados na sociedade como um todo - não deixando de afirmar que a família é a instância social encarregada da educação sexual de seus(suas) filhos(as), estando a escola frente às possibilidades de discussão dos diferentes olhares da sexualidade (BRASIL, 1998).

Como já afirmado por Louro (2016), são muitas as instâncias sociais que realizam a chamada pedagogia da sexualidade, inclusive a religião, instância social que dita normas e regula corpos através de suas crenças.

\section{Dúvidas e interesses sobre sexualidade}

Finalizando os questionários, os(as) alunos(as) registraram seus argumentos, questionamentos e sugestões de temáticas a serem trabalhadas, que auxiliaram quanto aos discernimentos das temáticas da sexualidade a serem trabalhadas didaticamente para o desfecho desta primeira etapa da pesquisa.

A seguir, destacam-se os registros que indicaram as temáticas da sexualidade abordadas.

Como que mulher namora uma com a outra? E o homem também? (Q2F, 20 EJA)

Não saber diferenciar na homossexualidade o "gênero" ativo do passivo. Eu não entendo que o homossexual nasce homossexual, pra mim vira homossexual. (Q4M, $\left.2^{\circ} \mathrm{EJA}\right)$

Eu mesmo me pergunto "porque nasce fêmea e quer virar macho?" Ou o outro lado, vice-versa. A pessoa que nasce homem e quer virar mulher. (Q6F, $\left.2^{\circ} \mathrm{EJA}\right)$

O que é sexualidade, a palavra a gente não entende muito. (Q8F, $\left.3^{\circ} \mathrm{EJA}\right)$

Eu gostaria de saber se sexualidade é a mesma coisa de se vestir roupas apertadas, curtas, andar rebolando. (Q9M, 30 EJA)

Todas, porque não sei falar sobre nenbuma. (Q12F, $\left.3^{\circ} \mathrm{EJA}\right)$

A minha curiosidade é de saber porque o adolescente é mais aceso na sexualidade. (Q15F, $\left.3^{\circ} \mathrm{EJA}\right)$

Gostaria de fazer sexo com duas mulheres juntas. (Q21M, $\left.4^{\circ} \mathrm{EJA}\right)$

Eu tenho dúvidas de um homem casado com uma mulher e tem desejo de ficar com outras mulheres. (Q23F, $4^{\circ}$ EJA)

Eu tenho curiosidade de saber qual é a sensação de um homem desejar o outro na boca. (Q24M, 4 EJA) Sobre o aborto, homossexual, bissexual, virgindade. (Q25F, $\left.4^{\circ} \mathrm{EJA}\right)$

Outra vez, fizeram-se notórias tanto a incompreensão do termo sexualidade, quanto as dissidências da orientação heterossexual, das inteligibilidades de gênero e a vontade excessiva da prática sexual. Estes registros acima sugeriram algumas atividades temáticas ligadas à transversalidade da sexualidade, principalmente as expressões e identidades de gênero, orientações sexuais e a discussão de 
práticas tidas como estranhas no campo social, como o aborto e a poligamia, por exemplo; ao contrário do estudo de Zanatta et al. (2016), no qual a educação sexual com adolescentes se demarcou pela ênfase na medicação e na reprodução dos corpos.

É válido ressaltar que, nessa pergunta, uma participante registrou por escrito sua opinião quanto à proposta temática desta pesquisa, posicionando-se contra o objetivo de estudo.

O tema é muito ruim, não está fazendo nada de bom. (Q7F, $\left.7^{\circ} \mathrm{EJA}\right)$

Quanto a esse posicionamento resistente ao discurso da sexualidade, Silva (2015) argumenta que

[...] há nessa temática uma grande lacuna a ser explorada, dentro e fora do campo educacional, uma vez que a intolerância à diversidade sexual implica não apenas na negação do direito à educação, mas também na negação de outros direitos subjetivos, inclusive o do direito à vida (...) Refletir sobre as formas com as quais a educação, sobretudo a de jovens e adultos, atua na manutenção, ou não, das hierarquias sexuais, nos dias atuais, parece-me indispensável e necessário. (SILVA, 2015, p. 8).

De acordo com os PCN (BRASIL, 1998), a modificação de posturas e atitudes em relação ao tema "será por meio do diálogo, da reflexão e da possibilidade de reconstruir as informações, pautando-se sempre pelo respeito a si próprio e ao outro, que o aluno conseguirá transformar, ou reafirmar, concepções e princípios, construindo de maneira significativa seu próprio código de valores." (BRASIL, 1998, p. 307).

Reforçando a postura voltada para o diálogo, Freire (1987) salienta que "não é no silêncio que os homens se fazem, mas na palavra, no trabalho, na ação-reflexão" (FREIRE, 1987, p. 44). Para este autor, a reflexão do diálogo torna o sujeito ativo; e o contrário, se negado, impossibilita o diálogo, não contribuindo para a sua ação-reflexão, ao que ele chama de práxis. Em outras palavras, é por meio do diálogo que os homens e as mulheres transformam o mundo, o qual se torna humanizado.

\section{Segunda fase: elaboração da SD}

Zabala (1998) define que as SD são "um conjunto de atividades ordenadas, estruturadas e articuladas para a realização de certos objetivos educacionais, que têm um princípio e um fim conhecidos tanto pelos professores como pelos alunos" (ZABALA, 1998, p.18).

Esse autor denomina as atividades da SD de unidades didáticas, unidades de programação ou unidades de intervenção pedagógica para se

[...] referir às sequências de atividades estruturadas para a realização de certos objetivos educacionais determinados. Estas unidades têm a virtude de manter o caráter unitário e reunir toda a complexidade da prática, ao mesmo tempo em que são instrumentos que permitem incluir as três fases de toda intervenção reflexiva: planejamento, execução e avaliação. (ZABALA, 1998, p.18).

Para Freire, antes da realização de qualquer atividade pedagógica, é necessário que se considere a realidade social e cultural dos sujeitos, os seus saberes e os fatores opressores, para que a educação, então, ocorra de forma humanista e emancipatória.

A pedagogia do oprimido, como pedagogia humanista e libertadora, terá, dois momentos distintos. O primeiro, em que os oprimidos vão desvelando o mundo da opressão e vão comprometendo-se na práxis, com a sua transformação; o segundo, em que, transformada a realidade opressora, esta pedagogia deixa de ser do oprimido e passa a ser a pedagogia dos homens em processo de permanente libertação (FREIRE, 1987, p. 23).

Nessa concepção, tendo em vista que o(a) aluno(a) carrega consigo algum conhecimento, as atividades da SD foram elaboradas a partir da discussão da Pedagogia do Oprimido de Paulo Freire, como 
também a continuidade da educação sexual foi tratada como uma estratégia didática permanente de reflexão.

Ao considerar as vivências, a SD foi elaborada a partir das demandas dos(as) educandos(as), suas vivências, a natureza do trabalho na zona rural, contemplando suas dúvidas, curiosidades e interesses em temáticas da sexualidade. Estas informações fornecidas no questionário serviram de base para o desenvolvimento das atividades sequenciais.

A sugestão temática da SD elaborada contém atividades organizadas de forma sequencial e pertinentes à realidade dos(as) educandos(as) e oferece diferentes modos de ensino e aprendizagem para que os(as) participantes empoderem o seu saber a fim de atender a possíveis questionamentos, dúvidas e curiosidades.

A SD foi desenvolvida com a inserção e a adaptação de atividades retiradas de outras fontes (cadernos, guias, livros), que são citadas, e por atividades elaboradas pela professora pesquisadora.

A seguir, apresenta-se a proposta temática da SD. Ela se divide em três atividades organizadas entre leitura de texto, dinâmica e oficina para as turmas da EJA.

\section{Parte 1}

\section{Texto: $O$ que é sexualidade?}

Trata-se de uma atividade "quebra-gelo", em que os(as) participantes deverão manifestar-se oralmente sobre a palavra em questão. Não é obrigatório que todos(as) se manifestem, apenas aqueles(as) que se sentirem à vontade para falar.

A conversa informal parte da necessidade de desconstrução de que falar em sexualidade é falar em sexo e do porquê da educação sexual no âmbito da escola. A atividade é uma adaptação e extração do caderno de capacitação do(a) professor(a), Sexualidade, pražer em conhecer (ECOS, 2001).

Duração: 90 minutos.

Objetivo: Conceituar o que vem a ser sexualidade, sexo e educação sexual.

Material: Lousa negra, giz e cópias do texto Sexualidade, valores e preconceitos.

\section{Desenvolvimento:}

1. $\mathrm{O}$ (a) professor(a) deve solicitar aos(às) participantes para que falem, sem censura, o que vem à mente quando ouvem ou se deparam com a palavra sexualidade (20 minutos).

2. Conforme forem falando, escreva as palavras no quadro.

3. Após as palavras serem ditas por todos(as) os(as) alunos(as) e transcritas na lousa, diferencie, explique e esclareça o que é sexualidade, sexo e educação sexual (25 minutos).

4. A seguir, entregue uma cópia do texto Sexualidade, valores e preconceitos retirado do caderno de capacitação Sexualidade, prazer em conbecer (ECOS, 2001, p. 16-19) para cada participante. O texto deve ser lido e discutido com os(as) alunos(as) a fim de se aprofundar o conhecimento sobre os assuntos oriundos das palavras geradoras desta atividade: sexualidade, sexo e educação sexual. Além disso, o texto apresenta um histórico da Educação Sexual no Brasil, possibilitando aos(às) alunos(as) conhecerem a respeito (45 minutos).

Texto: O que é sexualidade 


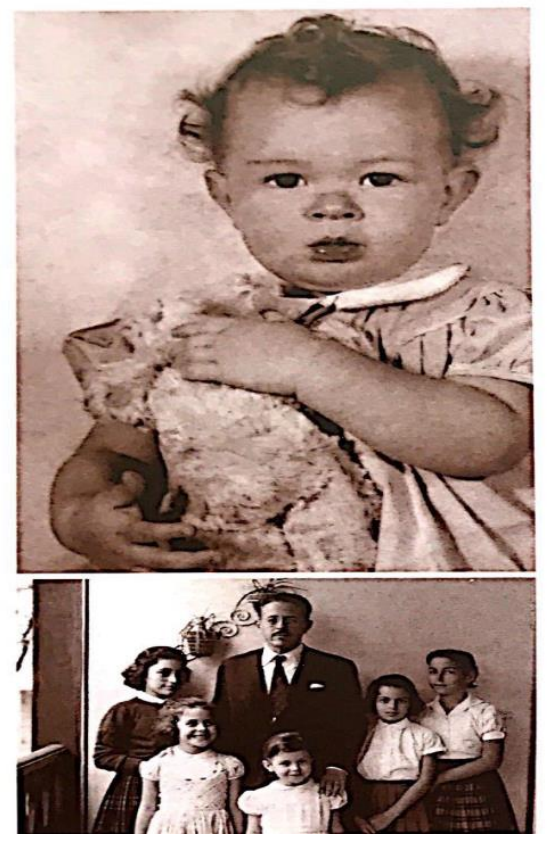

\section{Sexualidade \\ valores e preconceitos}

Nunca se falou tanto em sexo e sexualidade como agora. Mas será que as pessoas sabem, realmente, do que estão falando?

Sexualidade envolve, além do nosso corpo, nossa história, nossos costumes, nossas relações afetivas, nossa cultura. É muito mais do que sexo, uma simples parte biológica do corpo que permite a reprodução.

Falar de sexualidade é falar da própria vida. 


\section{E qual é o papel da escola?}

A escola traz os conhecimentos que nos ajudam a entender e enfrentar os desafios da vida! Ela tem um papel muito importante no desenvolvimento da sexualidade dos jovens.

Educação Sexual significa acabar com tabus e crendices, garantir maior igualdade nas relações entre mulheres e homens e, conseqüentemente, diminuir os casos de jovens portadores do virus da Aids e outras Doenças Sexualmente Transmissiveis, além de reduzir os casos de gravidez na adolescência.

Os alunos não são obrigados a estudar sexualidade como fazem com as disciplinas regulares, com provas e exames finais. Mas a escola deve abrir espaço para a discussão de temas ligados à sexualidade e à reprodução. Você, educador, educadora, deve estar preparado para isso. E há muitas questões a serem debatidas e esclarecidas. Uma troca de informações enriquecedora para todos, para você também. Ou alguém duvida de que os jovens têm muito a nos ensinar?

Nunca se viu tanta ênfase na discussão da sexualidade como depois do surgimento da epidemia da Aids. Apesar disso, ainda é difícil para muitas familias e educadores conversar sobre esses assuntos com as crianças e os adolescentes. Do ponto de vista da escola, também tem sido difícil inserir a Educação Sexual no seu cotidiano. Mas isto está mudando.

\section{Sexualidade história de valores}

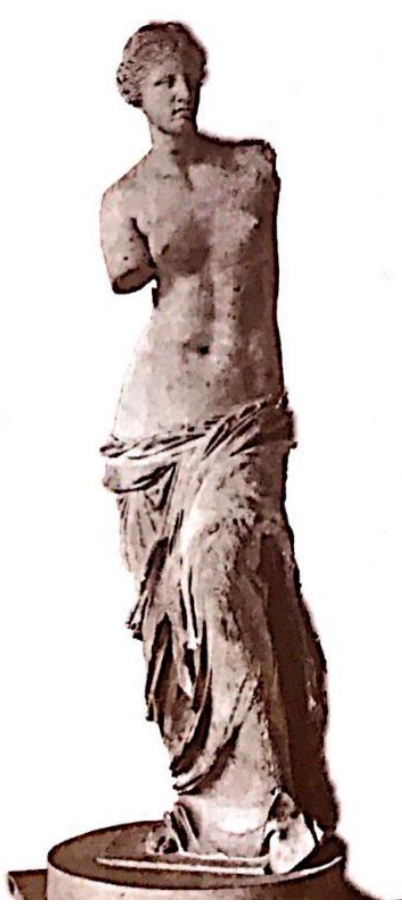

Hoje, é muito comum associarmos felicidade à busca do prazer, inclusive sexual. Mas nem sempre foi assim; depende da época e dos costumes. Diversas religiões valorizam a busca da felicidade eterna pela negação dos prazeres imediatos; acreditam que pelo jejum, pelo isolamento e pela castidade, ou seja, pela ausência de relações sexuais, os seres humanos podem alcançar maior desenvolvimento espiritual.

0 cristianismo fixou este conceito na cultura ocidental. Na época de seu surgimento, ele negou os ideais gregos de valorização do corpo e pregou o desenvolvimento da espiritualidade.

A revalorização do corpo só veio a acontecer no Renascimento, lá pelos séculos XV, XVI. Nessa época, o mundo vivia muitas 


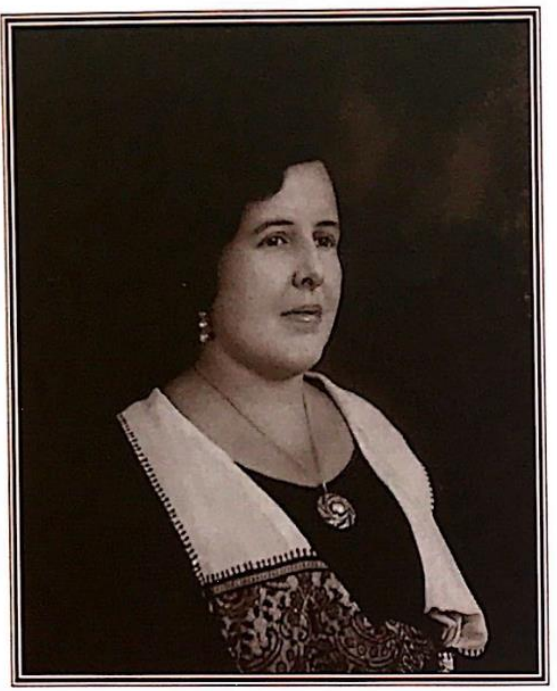

mudanças, aconteciam as grandes navegações, a imprensa, a reforma religiosa dos protestantes. Viviam gênios como Leonardo da Vinci e Michelangelo. 0 Renascimento retoma valores da Grécia antiga, que cultuava os prazeres e as artes.

Apesar de tantas mudanças, a forma de nossa civilização lidar com a sexualidade, baseada na repressão, no medo e na culpa, mantém-se até os nossos dias, de forma atenuada. No Ocidente, as mulheres eram simbolos de pureza e castidade. Durante séculos foram impedidas de manifestar sua sexualidade. Hoje, buscam a igualdade em todos os niveis.

0 século XX despontou com grandes novidades. A sociedade industrial dominada pelas fábricas foi se transformando na sociedade da informação, com seus computadores e sua economia multinacional. As descobertas científicas e o desenvolvimento tecnológico permitiram grandes mudanças em todos os setores sociais. As mulheres começaram, então, uma longa batalha, para ter direitos iguais aos dos homens, a partir da conquista do direito ao voto (no Brasil, isso só aconteceu em 1932).

Com a expansão dos ensinos médio e superior conseguiram novas oportunidades profissionais e ampliaram seu espaço

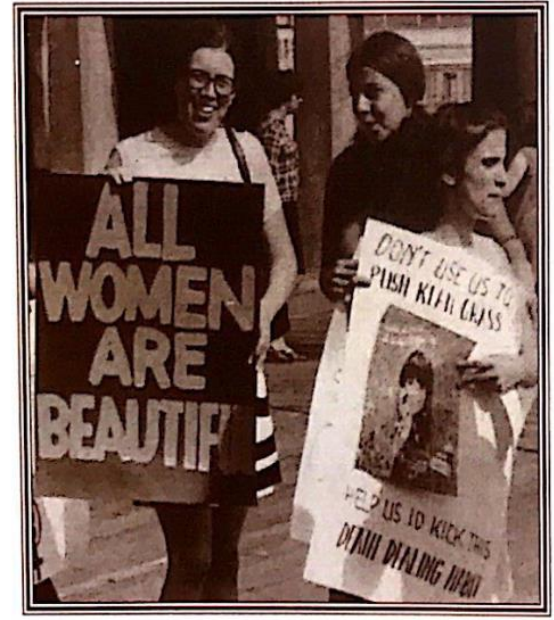

"Todas as mulheres são bonitas" - essa era um das palavras de ordem das feministas americanas na década de 1960. na sociedade. Chegaram aos anos de 1970 organizadas em movimentos feministas, prontas para debater e assumir sua sexualidade e novos papéis na sociedade.

Mas a questão do prazer e da sexualidade continua a ser um assunto dificil para muita gente.

As revistas, os filmes, os programas de TV, os catálogos de moda, outdoors, os veículos de comunicação exibem exaustivamente imagens com forte apelo sexual. 0 culto ao corpo e à sexualidade se tornou muito mais presente na vida das pessoas. Isso não quer dizer que as pessoas estejam mais abertas para debater sua sexualidade, livres de tabus e medos. Os valores conservadores ainda permeiam nossa forma de encarar o sexo como coisa proibida que, mesmo sendo prazerosa, deve ser mantida fora dos ambientes de respeito, como a casa e a escola. Mas é a partir da educação e da discussão em familia e na escola que esses valores podem mudar. 


\section{Educação Sexual no Brasil}

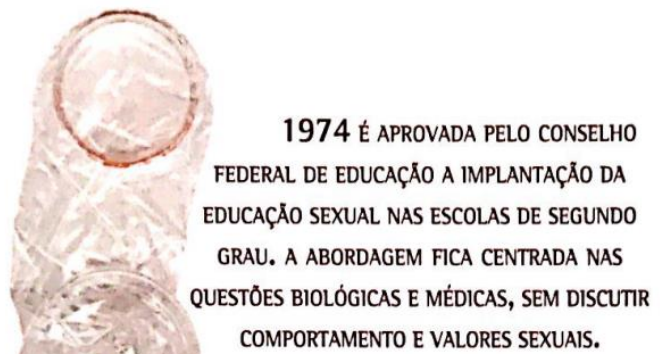

DÉCADA DE 1980 COM 0 FIM DA DITADURA MILITAR E A ABERTURA POLITICA, VOLTA A CRESCER O DEBATE SOBRE A NECESSIDADE DE EDUCAÇÃO SEXUAL NAS ESCOLAS. 0 INTERESSE É GUIADO, PRINCIPALMENTE, PELA PREOCUPAÇÃo COM A GRAVIDEZ NA ADOLESCÊNCIA E PELO SURGIMENTO DE UMA DOENÇA LETAL, A AIDS.

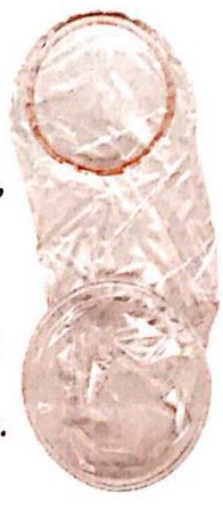

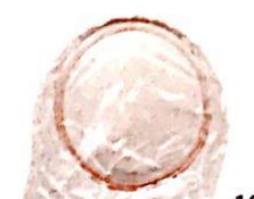

1976 O GOVERNO DEIXA DE SE RESPONSABILIZAR PELA EDUCAÇÃO SEXUal para centrar sua atuaçáo EM TEMAS SOCIAIS E ECONÔMICOS. A EDUCAÇÃO SEXUAL VOLTA A SER UMA ATRIBUIÇÃO DA FAMILIA.

1998 O MINISTÉRIO DA EDUCAÇÃO E DESPORTO INCLUI A EDUCAÇÃOO SEXUAL NOS PARÂMETROS CURRICULARES NACIONAIS - PCN', NÃO OBRIGATÓRIA, MAS RECOMENDADA PARA AÇÕES DENTRO DA ESCOLA. 0 TEMA É DIVDIDO EM BLOCOS DE CONTEÚDO PARA OS QUATRO CICLOS DO ENSINO FUNDAMENTAL.

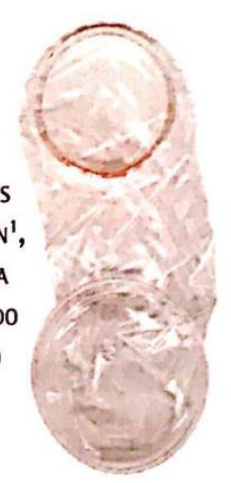

'0 professor encontrará, no texto dos Parâmetros Curriculares Nacionais, a expressão Orientação Sexual. Entretanto, neste manual, adotaremos o termo Educação Sexual, por ser mais comumente utilizado.

Fonte: Adaptação e extração do caderno de capacitação Sexualidade, prazer em conhecer. ECOS, 2001, p. 16-19 (Cadernos). 


\section{Parte 2}

\section{Dinâmica de grupo: Estereótipos e papéis de gênero}

Duração: 90 minutos.

\section{Objetivos:}

- Perceber como os homens e as mulheres são socialmente representados(as).

- Relacionar os estereótipos de gênero com as aprendizagens que vão sendo adquiridas ao longo da vida, em diferentes áreas do conhecimento.

- Compreender a importância de uma comunicação assertiva para assegurar a igualdade de gênero.

\section{Materiais:}

- Imagens de personagens femininas e masculinas de desenhos animados da Disney do conhecimento dos sujeitos.

- Cópias de textos retratando estudos de caso sobre papéis de gênero.

\section{Desenvolvimento:}

I. Divida a turma em duplas.

II. Apresente aos(às) alunos(as) diferentes personagens femininas e masculinas de desenhos animados. III. Solicite a alguns(mas) alunos(as) que contem, brevemente, a história de cada um(a) dos(as) personagens de desenhos animados apresentados(as).

IV. Peça para que cada dupla faça uma reflexão com base nas questões apresentadas a seguir. As duplas terão o prazo de 30 minutos para realizarem a reflexão. Neste momento, entregue a cada dupla uma folha de papel A4 e caneta para realizarem as anotações de suas reflexões.

\section{Questões para discussão}

1) Qual é a característica dominante nos personagens do gênero masculino?

2) Qual é a característica dominante nas personagens do gênero feminino?

3) Qual o papel desempenbado pelo(a) personagem?

4) A quem é atribuido com mais frequência o "papel" de herói/ heroína?

5) A quem é atribuido com mais frequência o "papel" de indefeso(a)?

6) Qual é o(a) personagem mais forte?

7) Qual é o(a) personagem mais delicado(a)?

V. Após a reflexão, disponibilize a cada dupla um caso sobre papéis de gênero. Solicite às duplas que leiam o seu caso e que encontrem uma resposta para a situação exposta.

VI. Após cada dupla encontrar a solução para o seu estudo de caso, deverá ser feita a leitura e apresentação de cada dupla para os demais alunos(as), apresentando a solução encontrada. Nesse momento, $\mathrm{O}(\mathrm{a})$ professor(a) deve solicitar às demais duplas que questionem as soluções encontradas e ao grupo que está a apresentar que defenda a sua solução, através de argumentos convincentes. Repita o processo até que todos os casos sejam apresentados e discutidos. Esse momento tem duração de cerca de 45 minutos.

VII. Para finalizar, com base nas "Questões para discussão", promova um pequeno debate, de 15 minutos, sobre a importância dos papéis de gênero nas relações humanas.

\section{Questões para discussão}

1. É fácil ou dificil olhar para os papéis de homem e mulher de uma forma nova e não tradicional? Por quê?

2. Como é que os homens ou as mulheres aceitam as alterações aos papéis de gênero tradicionais? Por quêe?

3. Os seus pais chegariam às mesmas ou a diferentes soluçöes?

4. Qual o estudo de caso mais difícil? Por quê?

5. Se pudessem faz̧er uma alteração no papel de gênero masculino, qual seria? E no papel de gênero feminino, qual seria? 
Imagens: Personagens femininas e masculinas de desenhos animados
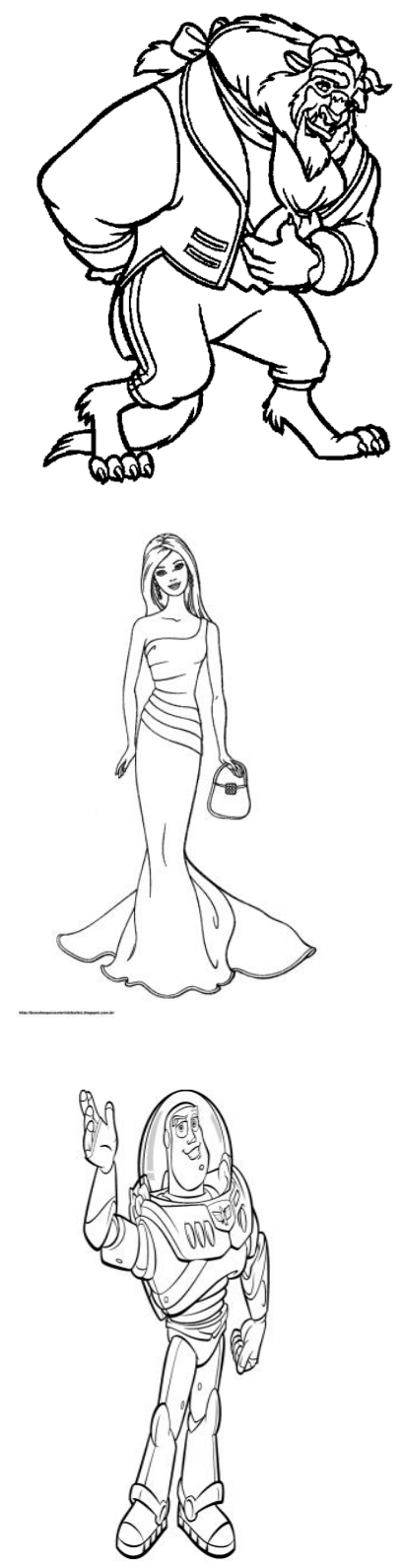
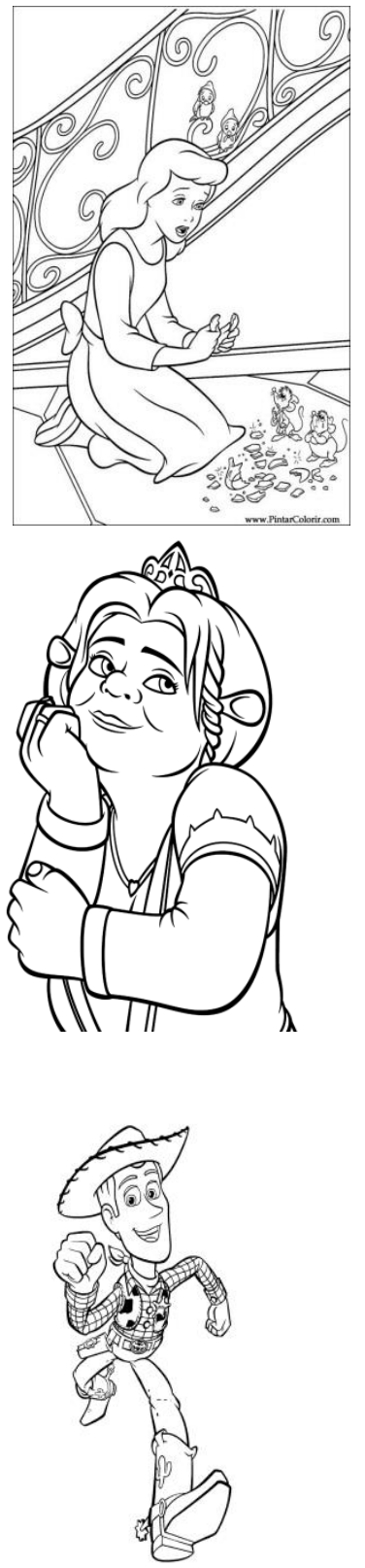

Fonte: Google imagens.
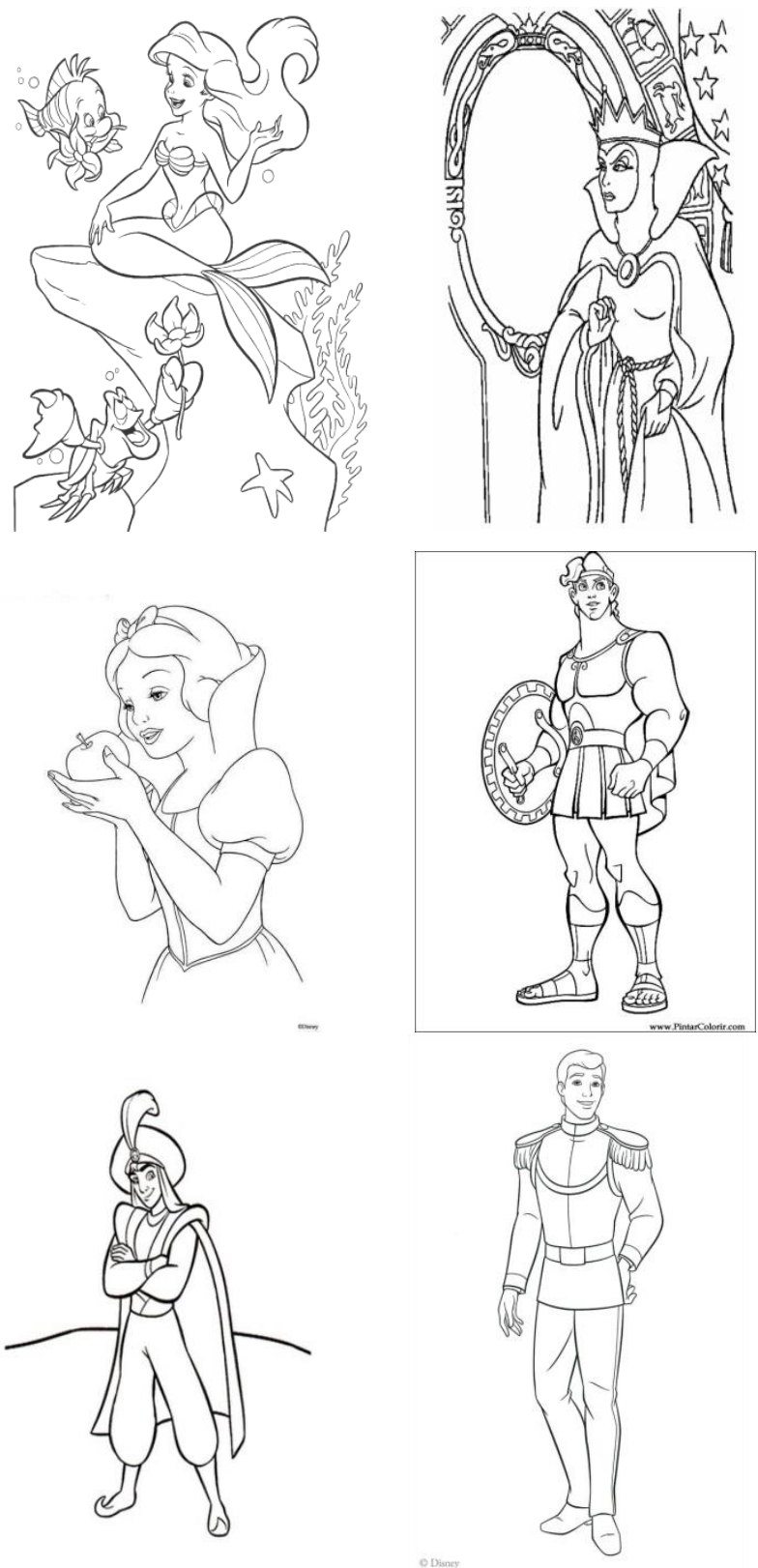

Textos: Estudos de caso sobre papéis de gênero

\section{Caso 1}

O Tomé está prestes a perguntar à Joana, pela primeira vež, se ela quer sair com ele, quando ela se dirige a ele e pergunta: "Tomé a feira livre da comunidade do assentamento vai iniciar hoje e en queria muito ir e gostaria que fosse comigo. Está livre hoje à noite?" O Tomé não tem planos para a noite e queria muito ir à feira com a Joana, mas gostava de ter sido ele a convidar. Ele pensa responder-lhe que está ocupado.

\section{O que pode o Tomé dizer ou fazer?}

\section{Caso 2}

Foi oferecida à Carlota a possibilidade de vir a ser tratorista da comunidade assentada em uma plantação de milho da associação cooperada. Ela fica toda contente e corre a contar ao João, o seu noivo. Tinham 
planejado se casar no ano seguinte e desta forma ela poderá começar a ganhar bom dinbeiro para a vida em conjunto. O João ouve-a em silêncio e no fim diz "penso que não posso casar com uma tratorista, Carlota. O que dirão as pessoas? Terá que escolher entre mim e essa profissão!"

O que pode fazer a Carlota?

\section{Caso 3}

O Samuel quer comprar uma boneca para o aniversário do seu sobrinho, mas o seu amigo José diz. "Nem pense nisso!" O Samuel explica-lhe que a boneca poderá ajudar o sobrinho a tomar conta de alguém e a ser carinhoso, mas o José argumenta que apenas fará com que o menino se torne uma "menininha"! O Samuel sabe que tem razão, mas fica preocupado com o que o José poderá contar aos seus amigos da comunidade assentada.

\section{O que deve o Samuel fazer?}

\section{Caso 4}

A Paula e o Fernando têm se encontrado há vários meses e as coisas têm corrido bem entre eles. Os pais dela aprovam esta relação e na escola do assentamento ela é conhecida por ser a namorada dele. Contudo, ultimamente o Fernando tem posto mais pressão na Paula do que ela consegue suportar. Quando ela diz. "Não" ele diz-lhe que o papel dela, como mulher, é agradar-lhe e fazê-lo feliz:

O que the pode dizer a Paula?

\section{Caso 5}

A Sandra e o Mário estão a discutir por causa da irmã Patrícia e do seu marido Roberto. A Sandra tem reparado que ultimamente a Patrícia aparece com imensas nódoas roxas nos braços e ombros, tendo mesmo na última semana aparecido com um olho roxo. O Mário diz-lhe que a Patrícia tem andado muito "saída da casca" e que aquela é a forma do Roberto lhe mostrar quem é que manda lá em casa. A Sandra olha para o Mário e abana a cabeça. Ela acha que a violência nunca é a solução.

\section{O que pode a Sandra fazer?}

\section{Caso 6}

A Carmen decidiu ter relações sexuais com o namorado, o Gabriel. Portanto, resolve ir até cidade e procurar uma farmácia para comprar preservativos, mas a sua amiga Tânia diz-lhe "as mulheres não compram preservativos! Isso é função dos homens".

Que pode a Carmen dizer e fazer?

\section{Caso 7}

No assentamento, a Susana e o Miguel estão juntos há cerca de um ano. Quando resolvem dar um passeio na feira da comunidade assentada, a qual pertencem, o Miguel sempre paga todas as compras e toma a maioria das decisões relativamente aonde vão, o que fazem e o que compram. Na aula de formação cívica da Susana tem-se falado do papel das mulheres relativamente à divisão das contas, das saídas e ao seu papel nas decisões dos planos do casal. Quer a Susana quer o Miguel trabalham coletivamente na comunidade assentada e ganham pouco dinheiro. Pelo que juntarem, o dinheiro de ambos, para pagarem o que fazem juntos faz sentido para a Susana, mas o Miguel fica furioso só de pensar nisso. Ele diz que ela não acha que ele seja homem suficiente para tomar conta dela.

O que pode a Susana dizer ao Miguel?

Fonte: Adaptação de extração de Caderno Presse $3^{\circ}$ Ciclo. Administração Regional de Saúde do Norte, I.P. Departamento de Saúde Pública. p. 101-108.

\section{Parte 3}

\section{Oficina: Direitos sexuais e reprodutivos}


Objetivo: Conhecer os direitos sexuais e reprodutivos (DSR) e avaliar em que medida eles são respeitados em nossas realidades.

Duração: 90 minutos.

Materiais: Recursos audiovisuais (notebook, data show, caixa de som e vídeo diferenciando os DSR, cópias de textos informativos, cartaz em E.V.A., papel craft, cartolina ou papel A4, pincéis atômicos, fita crepe).

\section{Desenvolvimento:}

a) Realize uma aula expositiva dialogada sobre os Direitos sexuais e reprodutivos (DSR) em apresentação de slides (recursos do Power-Point) com duração de 25 minutos. Em seguida, para firmar a compreensão dos DRS e diferenciá-los entre si, apresente o vídeo da série "Fala direto comigo", disponível no You Tube (https://www.youtube.com/watch?v=-3VpAL5iDfI), o qual tem duração de 3 minutos e 27 segundos. b) Após a apresentação da aula, divida os(as) discentes em três grupos. Os mesmos deverão criar duas situações dramatizadas: uma em que houve desrespeito aos direitos sexuais e/ou reprodutivos, e outra em que esses direitos foram respeitados. Nesse momento, distribua para os grupos textos de apoio sobre os DSR, tais como a Lei Maria da Penha, a Declaração dos Direitos Humanos etc., que auxiliem ou sirvam de sugestão para as dramatizações grupais (10 minutos).

c) Cada grupo deverá realizar a dramatização para cada caso em 3 minutos.

d) Após as apresentações, o(a) professor(a) deverá discutir com os(as) participantes os assuntos que emergirem e, a partir daí, realizar os esclarecimentos necessários para a elucidação das dúvidas e curiosidades.

\section{Fonte:}

Adaptado de Direitos sexuais e direitos reprodutivos (slides). ARENDET, Hannah. Disponível em:

http://www.sociedadesemear.org.br/arquivos/20111025145137_direitossexuaisedireitosreprodutivos.pdf. Acesso em: 27 de maio de 2017.

Adaptado e extraído de Saúde e prevenção nas escolas: guia para a formação de profissionais de saúde e de educação/Ministério da Saúde, Secretaria de Vigilância em Saúde. - Brasília: Ministério da Saúde, 2006. p. 83-86 - (Série A. Normas e Manuais Técnicos).

\section{CONSIDERAÇÕES FINAIS}

Durante as leituras dos aportes referenciais que amparam a ES na escola, constatou-se uma fragmentação e não uma continuidade das propostas entre os PCN e a BNCC - fato este que reforça a necessidade de um documento que ampare as discussões da sexualidade e do gênero, nas salas de aula, da modalidade EJA, como também dê autonomia ao trabalho do(a) professor(a) para que ele(a) discuta e faça a reflexão do contexto que seus(suas) alunos(as) vivenciam, no atual cenário político e social. Em específico, para as populações menos favorecidas socialmente, como as escolas de assentamento dos movimentos sociais.

Neste exposto, as escolas de assentamento são espaços sociais de sujeitos ativos e participativos, de múltiplos corpos e tipos de sexualidade, marcados por suas origens e crenças. Desconsiderar estes sujeitos seria padronizá-los a uma educação inadequada, esquecendo-se de suas identidades, particularidades e diversidades, enquanto sujeitos do campo.

Mediante a proposta educativa da ES, constata-se que os sujeitos da EJA, especificamente desta escola de assentamento, demandaram esclarecimentos e reflexões quanto à construção social e cultural da sexualidade a partir das suas vivências.

Neste viés, a EJA, constituída por diversos sujeitos, não deve ser considerada mera recompensa dos estudos não concluídos durante a infância ou adolescência, mas sim como um espaço de discussão e reflexão do cotidiano e experiências dos(as) estudantes.

Dessa forma, as atividades da SD sugerida, de acordo com as particularidades dos(as) participantes, pretendem contribuir para a conscientização do conceito de sexualidade, a compreensão e o respeito das diferenças de gênero, sinalizando para a importância da educação sexual no espaço escolar. 
Logo, as atividades da SD, além de considerarem o contexto dos(as) estudantes das escolas de assentamentos, devem ser uma intervenção pedagógica contínua desenvolvida ao longo dos períodos da EJA. Devido à sua relevância, verifica-se que realizar a ES sob a ótica histórica e cultural de um determinado grupo social significa romper com as barreiras impostas nos espaços escolares.

Por fim, sugere-se que outras pesquisas e intervenções pedagógicas devam ser realizadas sobre o tema, a fim de se ampliar a abordagem no conjunto ES, EJA e escola de assentamento/EC.

\section{REFERÊNCIAS}

ALTMANN, Helena. Orientação sexual nos Parâmetros Curriculares Nacionais. Estudos Feministas. $2^{\circ}$ semestre/2001. p. 575-585.

BELL, Judith. Criando e aplicando questionários. In: Projetos de Pesquisa. Guia para pesquisadores iniciantes em Educação, Saúde e Ciências Sociais. 4ª ed. Porto Alegre: ArtMed, 2008, p. 119-133.

BRASIL. Constituição (1988). Constituição da República Federativa do Brasil: texto constitucional promulgado em 5 de outubro de 1988, com as alterações determinadas pelas Emendas Constitucionais de Revisão nos 1 a 6/94, pelas Emendas Constitucionais n ${ }^{\text {os }} .1 / 92$ a 91/2016 e pelo Decreto Legislativo no 186/2008. - Brasília: Senado Federal, Coordenação de Edições Técnicas, 2016. 496 p. ISBN: 978-857018-698-0. Disponível em: https://www2.senado.leg.br/bdsf/bitstream/handle/id/518231/CF88_Livro_EC91_2016.pdf. Acesso em: 17 jan. 2019.

BRASIL. Lei $\mathbf{n}^{\mathbf{0}}$. 9.394, de 20 de dezembro de 1996. Estabelece as diretrizes e bases da educação nacional. Brasília, DF, 20 de dez. 1996. Disponível em: http://portal.mec.gov.br/seesp/arquivos/pdf/lei9394_ldbn1.pdf. Acesso em: 19 out. 2018.

BRASIL. Parâmetros Curriculares Nacionais: Pluralidade Cultural, orientação sexual. Secretaria de Educação Fundamental. Brasília: MEC/SEF, 1998, 436 p.

BRASIL. Resolução $\mathbf{n}^{\mathbf{o}}$. 466, de 12 de dezembro de 2012. Aprova as diretrizes e normas regulamentadoras de pesquisas envolvendo seres humanos. Disponível em: http://conselho.saude.gov.br/resolucoes/2012/Reso466.pdf. Acesso em: $1^{\circ}$ jun. 2016.

BRASIL. Resolução $\mathbf{n}^{\mathbf{0}}$. 510, de 07 de abril de 2016a. Aprova as diretrizes e normas regulamentadoras de pesquisas envolvendo seres humanos. Disponível em: http://conselho.saude.gov.br/resolucoes/2016/reso510.pdf. Acesso em: 28 maio 2018.

BRASIL. Base Nacional Comum Curricular. Proposta preliminar. Versão final. Brasília: MEC, 2016b. Disponível em: http://basenacionalcomum.mec.gov.br/images/BNCC_publicacao.pdf. Acesso em: 08 out. 2017.

BRASIL. Base Nacional Comum Curricular. Proposta preliminar. Versão final. Brasília: MEC, 2017. Disponível em: portal.mec.gov.br. Acesso em: 12 out. 2018.

BRASIL.Base Nacional Comum Curricular. Versão final. Brasília: MEC, 2018. Disponível em: http://basenacionalcomum.mec.gov.br/images/BNCC_EI_EF_110518_versaofinal_site.pdf. Acesso em: 29 dez. 2019.

CARVALHO, Anna Maria Pessoa de. Uma metodologia de pesquisa para estudar os processos de ensino e a aprendizagem em sala de aula. In: SANTOS, Flávia Maria Teixeira dos; GRECA, Ileana María (Orgs.). 
A pesquisa em ensino de ciências no Brasil e suas metodologias. $1^{\text {a }}$ ed. Ijuí: Unijuí, 2006, v. 1, p. $13-47$.

COSTA, Carolina da Purificação. Gênero e Educação de Jovens e Adultos (EJA): reflexões a partir das orientações curriculares da SEC-BA. In: Seminário Internacional Fazendo Gênero 11 \& 13th Women's Worlds Congress. Anais... Florianópolis, 2017, ISSN 2179-510X. 12 p.

DAMIANI, Magda Floriana et al. Discutindo pesquisas do tipo intervenção pedagógica. In: Cadernos de Educação | FaE/PPGE/UFPel. 2013, p. 57-67.

FACHIN, Odília. Fundamentos de Metodologia/Odília Fachin. $5^{\text {a }}$ ed. São Paulo: Saraiva, 2006.

FOUCAULT, Michel. História da sexualidade I: a vontade de saber mais. Tradução de Maria Thereza da Costa Albuquerque e J. A. Guilhon Albuquerque. 13a ed. Rio de Janeiro, Edições Graal, 1988. 149 p.

FREIRE, Paulo. Pedagogia do oprimido. 17ª Ed. Rio de Janeiro: Paz e Terra, 1987. 107 p.

IBGE, Instituto de Geografia e Estatísticas. 2010.

JULIÃO, Elionaldo Fernandes; BEIRAL, Hellen Jannisy Vieira; FERRARI, Gláucia Maria. As políticas de Educação de Jovens e Adultos na atualidade como desdobramento da constituição e da LDB. In: $\mathbf{P}$ O I É S I S - Revista do Programa de Pós-Graduação em Educação - Mestrado - Universidade do Sul de Santa Catarina. Unisul, Tubarão, v. 11, n. 19, p. 40 - 57, Jan./Jun. 2017. Disponível em: http://www.portaldeperiodicos.unisul.br/index.php/Poiesis/index. Acesso em: 17 jan. 2019.

LOURO, Guacira Lopes. Currículo, gênero e sexualidade - O "normal", o "diferente" e o "excêntrico". In: LOURO, Guaciara Lopes; FELIPE, Jane; Goellner, Silvana Vilodre (Orgs.) Corpo, gênero e sexualidade: um debate contemporâneo na educação. $3^{\mathrm{a}}$ ed. Petrópolis, RJ: Vozes, 2007. p. 41-52.

LOURO, Guacira Lopes. Pedagogias da sexualidade. In: LOURO, Guacira Lopes (Org.). O corpo educado: pedagogias da sexualidade. $3^{\text {a }}$ Ed. Belo Horizonte: Autêntica, 2016. p. 7-34. 2016.

MACHADO, Luane Cristina Tractz. Da educação rural à educação do campo: conceituação e problematização. In: Educere - XIII Congresso Nacional de Educação. IV Seminário Internacional de Representações Sociais, Subjetividade e Educação - SIRSSE. VI Seminário Internacional sobre Profissionalização Docente (SIPD/CÁTEDRA/UNESCO). Anais... ISSN 2176-1396. 2017. p. 1832218331.

MARTINS, Isabel. Dados como diálogo: construindo dados a partir de registros de observação de interações discursivas em salas de aula de ciências. In: SANTOS, Flávia Maria Teixeira dos; GRECA, Ileana María (Orgs.). A pesquisa em ensino de ciências no Brasil e suas metodologias. $1^{a}$ ed. Ijuí: Unijuí, 2006, v. 1, p. 297-321.

MEIRELLES, Elisa; Fernanda, SALLA. As escolas e o MST. In: Revista Nova Escola. Ano 29, Edição 274, Agosto 2014 (Revista Digital). Disponível em: novaescola.org.br. Acesso em: 29 jan. 2019.

MOLINA, Mônica Castagna; SÁ, Laís Mourão. Escola do Campo. In: Dicionário da Educação do Campo. CALDART, Roseli Salete et al (Orgs). Rio de Janeiro, São Paulo: Escola Politécnica de Saúde Joaquim Venâncio, Expressão Popular, 2012. p. 326-333.

MST, Princípios da Educação no MST (Caderno de Educação no 8), 1996. 29 p. Disponível em: http://www.reformaagrariaemdados.org.br/biblioteca/caderno-de-estudo/mst-caderno-da- 
educa $\%$ C3\% $\%$ A $\%$ C3\%A3o-n $\%$ C2\%BA-08- $\%$ E2\%80\%93-princ $\%$ C3\%ADpios-daeduca $\%$ C3\%A7\%C3\%A3o-no-mst. Acesso em: 02 nov. 2018.

MST, Movimento dos Trabalhadores Rurais Sem Terra. 2006.

PRADO, Di Paula Ferreira; REIS, Sônia Maria Alves De Oliveira. Educação de Jovens e Adultos: o que revelam os sujeitos? In: XVI ENDIPE - Encontro Nacional de Didática e Práticas de Ensino. Anais... UNICAMP, Campinas, SP, 2012. 11 p.

RAEL, Claudia Cordeiro. Gênero e sexualidade nos desenhos da Disney. In: LOURO, Guaciara Lopes; FELIPE, Jane; Goellner, Silvana Vilodre (Orgs.) Corpo, gênero e sexualidade: um debate contemporâneo na educação. $3^{a}$ ed. Petrópolis, RJ: Vozes, 2007. p. 160-171.

SANTIAGO, Nilda Gonçalves Vieira. A Educação de Jovens e Adultos numa perspectiva de letramento. 2014.9 p.

SANTOS, Nathany Ribeiro Lima dos; PEREIRA, Sara; SOARES, Zilene Moreira Pereira. Documentos curriculares oficiais assegurando a abordagem de gênero e sexualidade para a educação básica: um olhar para o ensino de ciências. In: V Simpósio Gênero e Políticas Públicas. Anais... Universidade Estadual de Londrina. 2018. 16 p.

SILVA, Jerry Adriani da. Educação de Jovens e Adultos - EJA, diversidade sexual, pessoas LGBTs e processos de socialização. In: V Seminário Nacional Formação de Educadores. Anais... Faculdade de Educação, Unicamp, Campinas/SP. 2015. 17 p.

SILVA, Jerry Adriani da. Diversidade Sexual na Educação de Jovens e Adultos (Eja). Pontifícia Universidade Católica do Rio de Janeiro. In: Revista Cátedra Digital. ISSN: 2525-7110. 2018. Disponível em: http://revista.catedra.puc-rio.br/index.php/diversidade-sexual-na-educacao-de-jovense-adultos-eja/. Acesso em: 01 jul. 2018.

SILVA, Maria José da; ARANTES, Adlene Silva. Questões de gênero e orientação sexual no currículo, a partir da BNCC. In: IV Congresso Nacional de Educação - CONEDU, Anais... 2017. 9 p.

SOARES, Marina Nunes Teixeira; GASTAL, Maria Luiza de Araújo. Educação sexual para jovens e adultos: contribuições ao ensino de Ciências à luz de uma abordagem emancipatória. In: SBEnBio Associação Brasileira de Ensino de Biologia. IV ENEBIO e II EREBIO da Regional 4. Anais... Goiânia, 18 a 21 set. 2012. 9 p.

SOUZA JUNIOR, Paulo Roberto. A questão de gênero, sexualidade e orientação sexual na atual Base Nacional Comum Curricular (BNCC) e o movimento LGBT'TQIS. In: Revista de Gênero, Sexualidade e Direito. e-ISSN: 2525-9849. Salvador, v. 4, n. 1, p. 1-21, Jan/Jun. 2018. Disponível em: http://www.indexlaw.org/index.php/revistagsd/article/download/3924/pdf. Acesso em: 21 abr. 2019.

WEEKS, Jerffrey. O corpo e a sexualidade. In: LOURO, Guacira Lopes (Org.). O corpo educado: pedagogias da sexualidade. $3^{a}$ Ed. Belo Horizonte: Autêntica, 2016. p. 35-81.

ZABALA, Antoni. A prática educativa: como ensinar. Trad. Ernani F. da Rosa - Porto Alegre: ArtMed, 1998. 224 p. ISBN 978-85-7307-426-0.

ZANATTA, Luiz Fabiano et al. A educação em sexualidade na escola itinerante do MST: percepções dos(as) educandos(as). In: Educação e Pesquisa, São Paulo, v. 42, n. 2, p. 443-458, abr./jun. 2016. DOI: http://dx.doi.org/10.1590/S1517-9702201606144556 
Submetido: 17/11/2019

Aprovado: 01/09/2020 